\title{
Improving the ventilation system at Rosh Pinah zinc mine
}

\author{
by E. Develo*, M. Pillalamarry*, and E. Garab ${ }^{\dagger}$
}

Paper written on project work carried out in partial fulfilment of B. Eng. (Mining Engineering)

\section{Synopsis}

Recent geological exploration at Rosh Pinah mine revealed that the mine's major production is shifting towards the western orefield, which will increase the demand for air flow to be supplied to this area. A snapshot of the ventilation survey carried out in December 2014 at the western orefield drill drive B (WOF-DDRB) showed that the air flow was well below the required standards. In order to improve the existing conditions, possible options were considered and simulated using Ventsim ${ }^{\mathrm{TM}}$ software.

The best option found was to replace the existing western orefield fans with the larger fans from the inactive southern orefield workings, to increase the air flow in the DDRB district. Simulation showed that as much as $20 \mathrm{~m}^{3} / \mathrm{s}$ of air can be received at the working faces of WOF 30 , compared to the previously received amount of $1.37 \mathrm{~m}^{3} / \mathrm{s}$. The economic analysis indicated that the above option can reduce the ventilation cost by N\$1.9 million annually. It was also noticed that after implementing this option together with other projects, the ventilation conditions in the mine were greatly improved and currently give no cause for concern.

Keywords

mine ventilation, simulation.

\section{Introduction}

A good mine ventilation system should be capable of providing adequate quantity and quality of air to all working faces, and is critical to the occupational health, safety, and comfort of underground employees (Luxbacher and Ramani, 1977; Exikis and Kapageridis, 2006). No ventilation system can remain adequate indefinitely; as the mine workings are extended, the ventilation characteristics such as system pressures, air volumes, leakages, and airway resistances change considerably. Continuous improvement of the ventilation system is needed to ensure compliance with health and safety regulations (Lovejoy, 2010). It also ensures that the right quality and quantity of air is delivered to all the necessary areas at the lowest possible cost. This can be achieved by identifying inefficient airways and poorly ventilated areas in the mine and planning how best to upgrade them.

The latest geological exploration shows that the focus of production at Rosh Pinah mine is shifting towards the western orefield (WOF). As mining progressed, the working areas have advanced away from the main fans, which increased the resistance to air flow drastically and resulted in increasing demands being imposed on the main fan in order to supply an adequate air flow. This process also created more leakage paths between the fan and the working areas, which has caused the air to short-circuit before it can reach the faces. Consequently, a much larger quantity of air has to be circulated by the fan so that the stipulated quantity reaches the face, which increases operating costs (Singh et al., 2004).

An investigation was carried out to optimize the existing ventilation system along the WOF at Rosh Pinah, in order to accommodate the growing ventilation demand. This entailed an evaluation of all the feasible alternatives available to improve air flow to the working faces (Mukherjee et al., 1982). The current distributions of air flow, pressure, leakages, and air quality throughout the main flow paths of the WOF were quantified by conducting a pressure-quantity survey. Survey data was used to identify ventilation inefficiencies along the WOF drives and also to simulate the current ventilation network. Finally, the ventilation network and regulators were modified in order to distribute sufficient fresh air at the working faces in the WOF with minimum cost. Ventsim ${ }^{\mathrm{TM}}$ software was used to simulate the ventilation network.

\section{Background}

Rosh Pinah is an underground mine that produces primarily zinc and lead. The mine is owned by Glencore and is located approximately $360 \mathrm{~km}$ southwest of Keetmanshoop in Namibia. This underground operation is $420 \mathrm{~m}$ deep and uses sill-and-bench open stoping methods. The mine workings are divided into

* Department of Mining and Process Engineering, University of Science and Technology, Namibia, Windhoek.

$\dagger$ Rosh Pinah Zinc Corporation, Rosh Pinah, Namibia.

(C) The Southern African Institute of Mining and Metallurgy, 2016. ISSN 2225-6253. Paper received Mar. 2016. 


\section{Improving the ventilation system at Rosh Pinah zinc mine}

different sections according to the location of the orebodies, which are termed the western, eastern, southern, and northern orefields. Figure 1 shows the layout of the mine sections at Rosh Pinah.

Rosh Pinah practices very high safety and health standards and the ventilation officers are required to conduct daily ventilation surveys before the underground employees enter a working area. If these areas do not meet the ventilation standards, no personnel are allowed to enter that particular area until the conditions are improved by the Rosh Pinah technical team.

\section{Ventilation network}

The WOF has three major ventilation intakes, namely the C-mine adit, Quick Access, and the 390 BME adit. The eastern orefield has one major intake, the eastern orefield adit. The intake to the southern orefield is the C5 access tunnel. Figure 2 illustrates the layout of the five main intakes at Rosh Pinah, including the eastern orefield adit. The intake air is passed through the decline while the exhaust air is returned to the atmosphere by an exhaust fan connected to a raise. Rosh Pinah has a complex ventilation network requiring efficient use and management of air control within the mine. The deeper sections of the mine are hot and humid, which necessitates the use of auxiliary ventilation.

Rosh Pinah currently has five main exhaust fans installed at the top of the worked-out stopes, which are responsible for extracting the return air out of the stopes and to the atmosphere. Maintenance on the main fans is carried out once every three months by the mine mechanics, and once yearly on contract maintenance. The specifications and locations of these fans are detailed in Table I.

\section{Simulation models}

The air flow requirement at the working faces was calculated according to the mine ventilation standards of Namibia (Ministry of Mines and Energy, 1992). The figure includes the requirements for machinery as well as personnel working at the face. Prior to the simulation, the current ventilation model of Rosh Pinah was updated with the new working areas by importing extended level plans (survey plans) as DXF files. The extended branches were drawn and edited in Ventsim. The ventilation network was then simulated with the new ventilation data, using various possible options and different control methods. The changes that could be made to the network were identified from the ventilation survey data. The following two options were considered for simulation.

\section{Option 1: redirecting the air flow}

The WOF decline intake has three portals, namely, Quick
Access, C-mine entrance, and C5 tunnel. This simulation was simply used to redirect the airflow through the WOF decline by placing a curtain at the entrance to the northern orefield intake tunnel, since no mining is taking place at this location.

A permanent stopping was also placed close to the Quick Access portals where the air moves towards the workshop and is returned to the Quick Access through a stope. The workshops are dormant and therefore ventilation is not needed. After the simulation, the airflow distribution was analysed. The location of the stopping along the WOF decline is indicated in Figure 3.

\section{Option 2: fan upgrade}

Since production is shifting towards the WOF, more air flow will be required in this area. Two J67 Airtec Davidson fans are installed at the southern orefield stope, which will be mined-out soon (Figure 4). The fan upgrade at WOF includes removing the existing Howden D7 fans, which supply $125 \mathrm{~m}^{3} / \mathrm{s}$ when operating in parallel, and replacing them with the two J67 Airtec Davidson fans from the SOF (Figure 4).

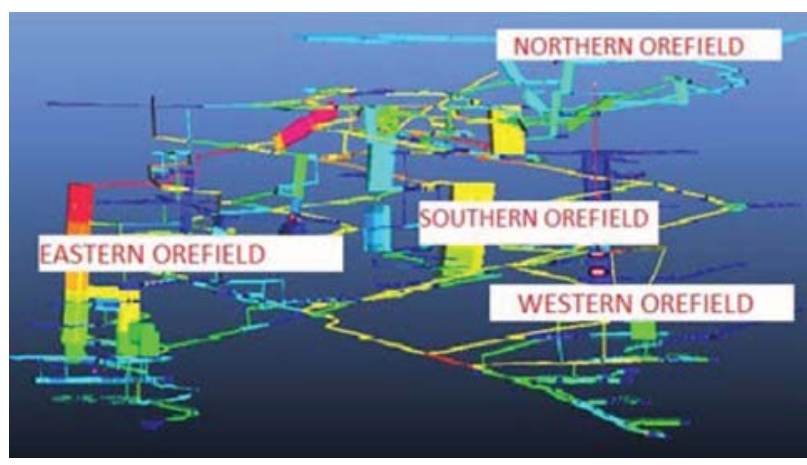

Figure 1-Layout of orefields at Rosh Pinah zinc mine

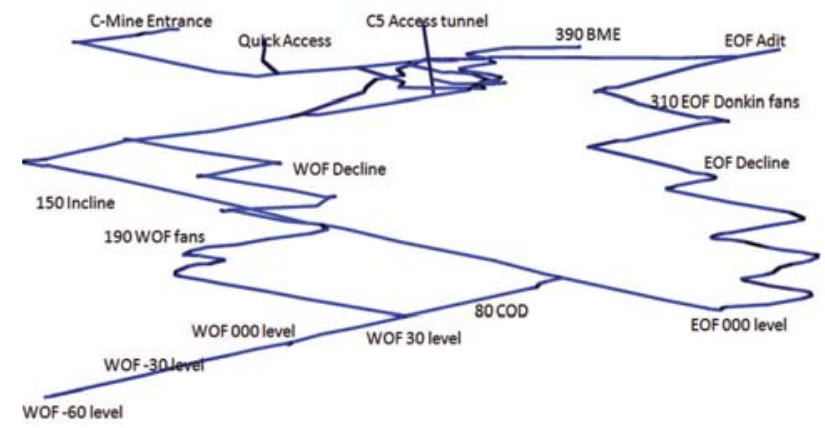

Figure 2-The five ventilation intakes at Rosh Pinah

\begin{tabular}{|c|c|c|c|}
\hline Fan type & Connection & Capacity & Location \\
\hline $\begin{array}{l}2 \times \text { centrifugal Donkin fans } \\
2 \times \text { axial flow Howden D7 fans } \\
1 \times \text { axial flow J67 Airtec Davidson fan }\end{array}$ & $\begin{array}{l}\text { Parallel } \\
\text { Parallel } \\
\text { Series }\end{array}$ & $\begin{array}{c}2 \times 160 \mathrm{~kW} \text { at } 180 \mathrm{~m}^{3} / \mathrm{s} \\
2 \times 110 \mathrm{~kW} \text { at } 125 \mathrm{~m}^{3} / \mathrm{s} \\
185 \mathrm{~kW} \text { at } 100 \mathrm{~m}^{3} / \mathrm{s}\end{array}$ & $\begin{array}{l}\text { EOF } 310 \text { level } \\
\text { WOF } 190 \text { level } \\
\text { Surface, SOF }\end{array}$ \\
\hline
\end{tabular}




\section{Improving the ventilation system at Rosh Pinah zinc mine}

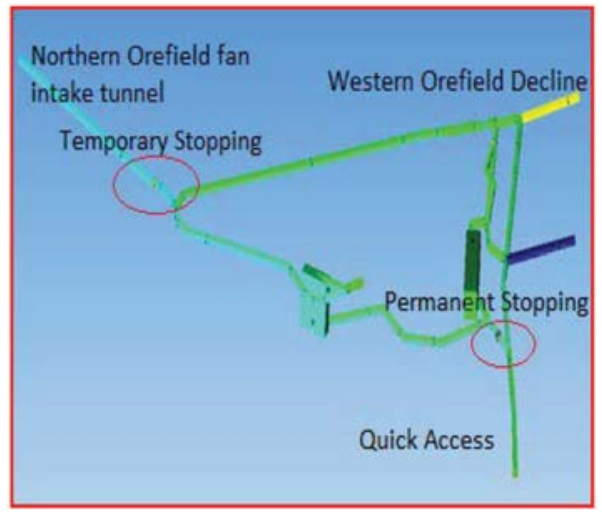

Figure 3-Location of temporary and permanent stoppings at WOF

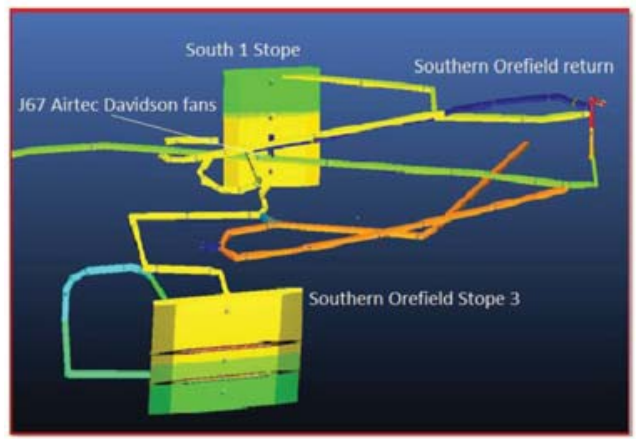

Figure 4-Location of J67 Airtec Davidson fans at SOF

Prior to the fan installation, a bulkhead with a width of 8 $\mathrm{m}$ and a height of $4 \mathrm{~m}$ was drawn at WOF level 30 to locate the fan. The purpose of this bulkhead is to reduce the shock losses that may occur if the fan was to be located perpendicular to the direction of the air flow. Three raises were planned from WOF 30 to WOF 90 to link the new fan location with the return raise at WOF 90. This is shown in Figure 5. The length of the raises from 30 level to 190 level is $163 \mathrm{~m}$. The diameter of the raise that was inserted is $4.0 \mathrm{~m}$. The new airflow distribution along WOF was then simulated. The new location of the fans at WOF is shown in Figure 5

\section{Results and discussion}

\section{Ventilation survey}

The objective of the survey was to assign resistances to all the branches in the ventilation network by quantifying the air flows and pressure drops (Nixon, 1983). Moreover, accurate quantity and pressure measurements are an absolute necessity since the validation of the computer-generated output is heavily dependent on the accuracy of the input data (Gelhn et al., 2008; Rostami, 2011). The characteristics of the existing mine ventilation system were determined by conducting an underground survey. The direction of the airflow and the location of intakes, returns, stoppings, etc. were determined by inspection of the mine plan.

The ventilation results below are a snapshot from December 2014. No personnel were allowed to enter the area due to the mine's safety and health policy. Since these are newly developed workings, the adequacy of the ventilation under the existing system was surveyed to improve the conditions in this area. However, no production was taking place at this area during the survey, and production will be started only after the ventilation conditions are improved.

\section{Gas concentration}

The oxygen concentration at all five working faces (no. 1, 5, 6,8 , and 9) in the WOF met the required minimum of $20 \%$. The methane concentration at the working faces was found to be negligible. The nitrogen oxide levels were minimal, and did not cause any major concern.

\section{Humidity}

High temperatures and humidity in an underground workplace may result in reduced performance and impair the attention of workers (Rostami, 2011). Therefore, it is important to study the humidity levels at the working face to ensure comfortable conditions. The humidity measured at all the working faces of WOF 30L was slightly above the maximum allowable level of $85 \%$ (Figure 6). A maximum humidity of $90 \%$ was measured at working face 8 . The humidity at all the other working faces at WOF level 30 was found to be satisfactory.

\section{Velocity and air flow}

The air flow required at the working faces of the mine was determined using the mining ventilation standards of Namibia (Ministry of Mines and Energy, 1992). Rosh Pinah mine makes use of Cat $\mathrm{AD} 30$ trucks in combination with scoops. Usually, there are a maximum of six personnel at a working face. The cross-sectional areas of the working faces are $22.7 \mathrm{~m}^{2}$, therefore, the calculated minimum required airflow at the working face is $18.2 \mathrm{~m}^{3} / \mathrm{s}$. The measured air flow at the working faces of the WOF is shown in Figure 7.

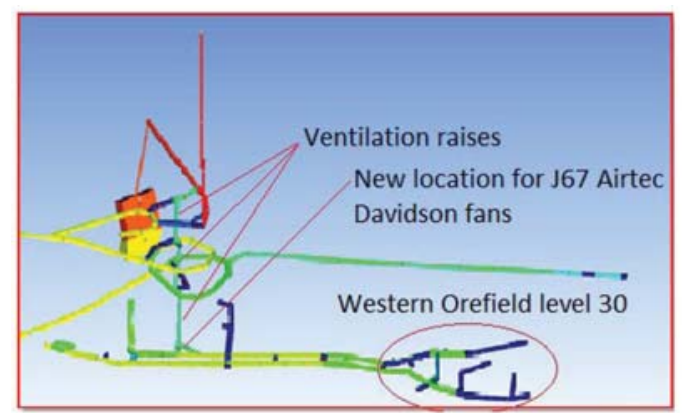

Figure 5-New location of the J67 fans at WOF

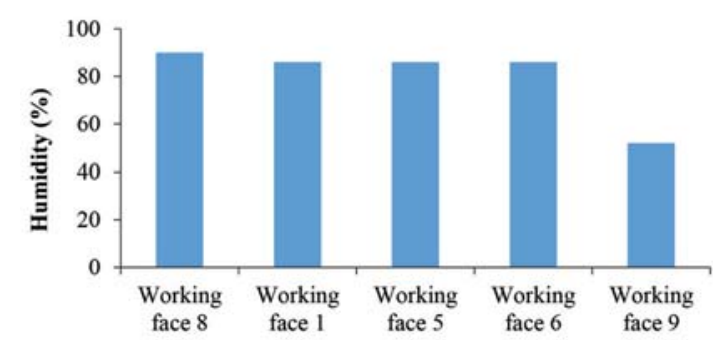

Figure 6-Measured humidity levels 


\section{Improving the ventilation system at Rosh Pinah zinc mine}

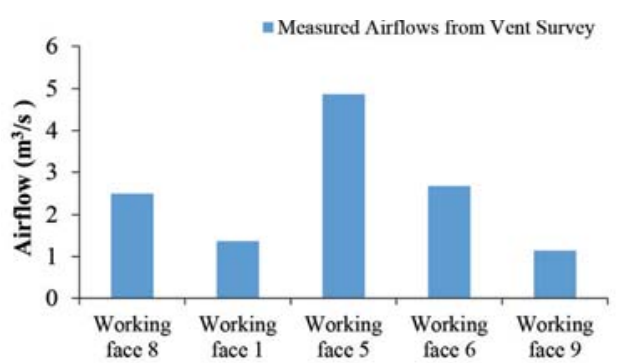

Figure 7-Measured air flow at the working faces

\section{Volumetric and fan efficiency}

The air flow entering the working faces was $41.0 \mathrm{~m}^{3} / \mathrm{s}$ compared to the total air flow of $11.41 \mathrm{~m} / 3 / \mathrm{s}$. reaching the working faces. The volumetric efficiency was therefore $27.83 \%$. In addition, the efficiency of the existing Howden fans during the ventilation survey was found to be only $67.1 \%$.

\section{Simulation results}

\section{Option 1: redirecting the air flows}

Sealing the entrance to the workshop near the Quick Access at level 370 and placing a curtain at the northern orefield fan tunnel entrance resulted in the air flow at the WOF increasing from $60 \mathrm{~m}^{3} / \mathrm{s}$ to $83 \mathrm{~m} / \mathrm{s}$. However, air flow at the working faces was still inadequate; this increase in air flow was rather supplied to other areas in the mine. The maximum air flow that was achieved was $11.2 \mathrm{~m}^{3} / \mathrm{s}$, and this was at working face 8 . The air flow entering the working faces increased slightly to $44 \mathrm{~m}^{3} / \mathrm{s}$. The air flow at the working faces after redirecting is shown in Figure 8.

\section{Option 2: fan upgrade and stope sealing}

By replacing the existing WOF fans with the southern orefield fans, the air flow increased significantly, meeting the regulatory requirements at all the working faces. The air flow entering the WOF was $122 \mathrm{~m} 3 / \mathrm{s}$, and the air flow at working face 8 increased to $25.2 \mathrm{~m}^{3} / \mathrm{s}$. The total air flow reaching the working faces was $103.2 \mathrm{~m} / \mathrm{s}$; the volumetric efficiency therefore is $68.8 \%$, and the rest of the air was leaking through the stopping to the return raise. The air flow at all five working faces is given in Figure 9. Working faces 1, 5, 6,8 at WOF 30 are parallel with working face 9 at WOF 90 .

\section{Cost considerations}

The costs of making changes to the ventilation network at Rosh Pinah were evaluated for option 2. The costs to replace the two main fans at WOF level 90 with the two fans at southern orefield level 262 (J67 Airtec Davidson fans) were determined.

Since the main fans are not new, the capital costs of alteration include the fan installation costs and the costs for drilling the three $160 \mathrm{~m}$ raises from 30 level to 90 level of WOF. According to the project planner at Rosh Pinah, the costs of drilling and blasting a raise is $\mathrm{N} \$ 710$ per metre, including labour costs. Hence:

Total costs of drilling and blasting the $160 \mathrm{~m}$ raise $=$
Costs of drilling a raise per metre $\times$ number of holes $\times$ length of raise

$$
=\mathrm{N} \$ 710 \times 21 \times 160 \mathrm{~m}=\mathrm{N} \$ 2385600
$$

Total capital costs to install the fans $=$ costs of drilling and blasting $(160 \mathrm{~m})$ raise + installation costs from contractor

$$
=\mathrm{N} \$ 2385600+\mathrm{N} \$ 288216=\mathrm{N} \$ 2673816
$$

Equivalent annual costs are therefore,

$$
(\mathrm{EAC})=\frac{320549 \times 0.1}{\left(1 \frac{-1}{(1.1)_{8}}\right)}=\mathrm{N} \$ 501190.81
$$

The annual operating costs for the two fans are (McPherson, 1993):

$$
\text { Operating costs }(\mathrm{N} \$)=\frac{P f t \times Q}{\grave{\eta}} \times \mathrm{e} \times 24 \times 365
$$

where

$P_{f t}=$ Fan total pressure $(\mathrm{kPa})$,

$Q=$ Air flow $\left(\mathrm{m}^{3} / \mathrm{s}\right)$,

$\mathrm{e}=$ Cost of electricity in $\mathrm{kWh}(\mathrm{N} \$)$

$$
\begin{aligned}
\text { Operating costs }(\mathrm{N} \$) & =\frac{2 \times 185}{0.671} \times 0.85 \times 24 \times 365 \\
& =\mathrm{N} \$ 4105842.027 \text { per year }
\end{aligned}
$$

The total yearly cost is obtained by adding the cost of developing the airways/raises and the annual operating cost of ventilation.

Total cost to implement option $2=\mathrm{N} \$ 501190.81+$

$\mathrm{N} \$ 4105842.027=\mathrm{N} \$ 4607032.84$

\section{Conclusions}

Ventilation survey results revealed that gas concentration and humidity levels at the western orefield decline met the Namibian ventilation standards and did not cause any major concern (Ministry of Mines and Energy, 1992). Since the

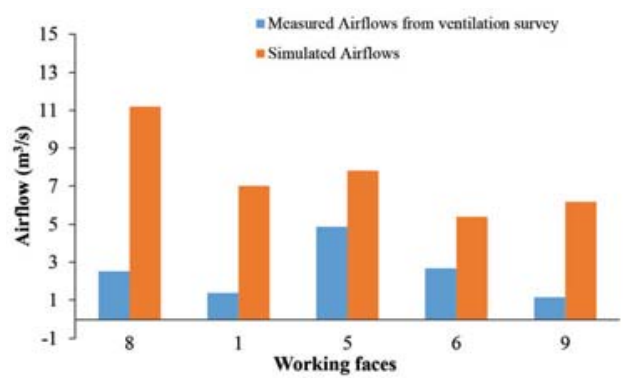

Figure 8-Simulated air flow vs. field measurements

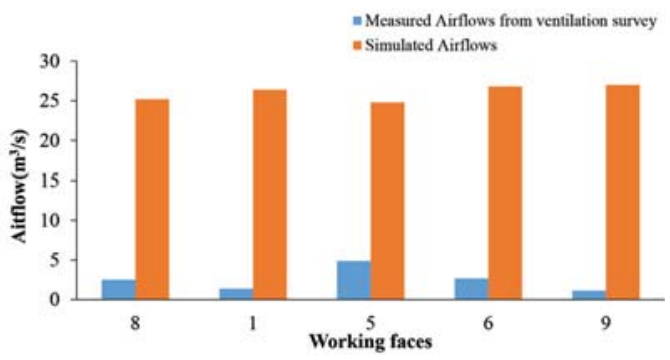

Figure 9-Simulated vs. measured air flow 


\section{Improving the ventilation system at Rosh Pinah zinc mine}

workings are still at the developing stage, the air flow measured at the western orefield decline was below the minimum required. The volumetric efficiency of the western orefield decline was found to be $27.3 \%$. The most feasible solution to increase the air flow at the working faces would be to replace the western orefield main fans with the southern orefield main fans. Along the western orefield decline, $25.23 \mathrm{~m}^{3} / \mathrm{s}$ of the air is flowing out of the western orefield into the northern orefield fan tunnels. No mining activity is currently taking place in this area; therefore it is recommended that the flow of air can be controlled by placing a brattice cloth at the entrance of the fan tunnel. Real-time air quantity and air quality control would reduce the effort of ventilation surveys. The real-time monitoring ventilation system, together with Ventsim ${ }^{\mathrm{TM}}$, could improve the accuracy of the simulation and provide the most accurate results.

\section{Acknowledgements}

The authors thank Rosh Pinah Zinc Corporation for the provision of data and the use of its facilities and ventilation measuring instruments during the investigation.

\section{References}

DucKWORTH, I.J. and LOWNDES, I.S. 2003. Modelling of auxiliary ventilation systems. Transactions of the Institution of Mining and Metallurgy, vol. 12 , no. 2. pp. 2-9

EXIKIS, A. and KAPAGERIDIS, I.K. 2006. Simulation of air and contaminant flow in underground mine ventilation networks. Proceedings of the 2nd International Conference on Advances in Mineral Resources Management and Environmental Geotechnology (AMREG 2006), Technical University Crete, Chania. pp. 89-93.

GLEHN, F.H., MARX, W.M., and BluHM, S.J. 2008. Verification and calibration of ventilation network models. Proceedings of the 12th U.S./North American Mine Ventilation Symposium 2008, University of Nevada, Reno, NV. Wallace, K.G. (ed.). Society of Mining Engineers of AIME. pp. 275-279.

Hartman, H.L., Mutmansky, J.M., Ramani, R.V., and Wang. Y.J. 1997. Mine Ventilation and Air Conditioning. Wiley, Hoboken, NJ.

Lovejoy, C. 2010. A breath of fresh air. Mining Magazine, July/August 2010. pp.16-21.

LUXBACHER, G.W. 2008. Developing input data for computer simulation of mine ventilation. Kentucky: Pennsylvania State University.

LuXBACHER, G.W. and RAmani, R.V. 1979. Optimization of coal mine ventilation systems. AIME Transactions, vol. 286. pp. 1801-1809.

McPherson, M. 1993. Subsurface Ventilation Systems. Chapmann \& Hall, New York. pp.25-120.

Ministry of Mines And EnERgy. 1992. Mine Health and Safety Regulations, 10th draft. Windhoek.

Nixon, T.R., Deakin, J.J., and RalPh, A.M. 1983. Ventilation analysis for mine planning and operation. Computers in Mining Symposium, Southern Queensland Branch, Australasian Institute of Mining and Metallurgy. pp 231-240.

Rostami, P., Danko, G., and Bahrami, D. 2011. Ventilation and climate simulation of development ends in metal mines. Proceedings of the SME Annual Meeting, Denver, CO. Preprint no. 11-135. pp. 732-735.

Singh, A.K., Ahmad, I., Sahay, N., Verma, N.K., and Singh, V.K. 2004. Air leakage through underground ventilation stoppings and in situ assessment of air leakage characteristics of remote filled cement concrete plug by tracer gas technique. Journal of the South African Institute of Mining and Metallurgy, vol. 104, no. 2. pp 101-106.

Tien, J. 2008. Determining the optimal mine regulator location using computer simulation. Peabody Coal Company, Kentucky. pp.2-6

WALLAce, K. and McPherson, M.J. 1983. The efficiency and economics of mine ventilation systems. TMS/AIME Meeting, Atlanta, GA, 6 March 1983. pp. 2-7. 